\title{
Indonesian indigenous plants as a source of antioxidants to treat gastrointestinal disorders
}

\author{
1,2, ${ }^{*}$ Sandrasari, D.A., ${ }^{1,3}$ Andarwulan, N., ${ }^{1}$ Faridah, D.N. and ${ }^{4}$ Dewi, F.N.A. \\ ${ }^{1}$ Department of Food Science and Technology, Faculty of Agricultural Technology, IPB University \\ ${ }^{2}$ Department of Food Tech, Faculty of Food Science and Health, Sahid University, 12780, Jakarta, \\ Indonesia \\ ${ }^{3}$ Southeast Asian Food and Agricultural Science and Technology (SEAFAST) Center, IPB University \\ ${ }^{4}$ Primate Research Center, IPB University, Bogor, Indonesia
}

\begin{abstract}
Article history:
Received: 6 December 2020

Received in revised form: 29

January 2021

Accepted: 21 April 2021

Available Online: 3 October 2021
\end{abstract}

\section{Keywords:}

Indonesian indigenous plants, Antioxidant,

Gastrointestinal disorders

DOI:

https://doi.org/10.26656/fr.2017.5(5).707

\begin{abstract}
Gastrointestinal disorders are the most common illnesses that affect people nowadays. Its prevalence and incidence have increased over the last decades. The majority of the people in Indonesia are still using indigenous plants as medicine to treat these infections or diseases. This study was aimed to determine the potential of Indonesian indigenous plants in treating gastrointestinal disorders. The plants were inventoried through searching articles such as Google Scholar, PubMed, ScienceDirect and Indonesian medicinal plants books. The keyword search term used was "gastrointestinal," "Indonesian," "medicinal plants," "antioxidant activity," and "phenolic compound,". A total of fifty-one species of indigenous Indonesian plants of 32 families were recorded as being used by the Indonesian population to treat gastrointestinal disorders. Gastrointestinal disorders that heavily utilize indigenous plants are diarrhoea, constipation, gastric ulcer and gastritis. Indonesian indigenous plants containing bioactive compounds such as alkaloids, flavonoids, saponins, tannins, steroids, terpenoids and phenolics that can serve as a source of antioxidants to treat gastrointestinal disorders. There were five Indonesian indigenous plants with the most potential as a source of antioxidants to cope with gastrointestinal disorders: Zingiber officinale L, Annona muricata, Phyllanthus niruri, Curcuma longa and Curcuma xanthorrizha.
\end{abstract}

\section{Introduction}

Traditional plants medicine has been known for a long time and used by the people of Indonesia. This process has been passed down from generation to generation, especially with the concept of back to nature make traditional medicine more desirable. Indonesian indigenous plants are Indonesian native plants from certain regions/ecosystems, including introduced species from other geographic areas but have evolved with the climate and geographic region of Indonesia (Andarwulan, 2012). Most people think that plants can be used as a traditional medicine because it has a lower side effect than chemical drugs. The original plant is widely used as an alternative medicine for an exogenous antioxidant that has been proven effective for treating a variety of ailments including indigestion (Madikizela et al., 2012). The ability of plants to treat gastrointestinal disorders because of their antioxidant compounds such as flavonoids, polyphenols, saponins, alkaloids, and terpenoids. Flavonoids and polyphenol compounds are antioxidants, antidiabetic, anticancer, anti-inflammatory and antiseptic, while alkaloids have strong antineoplastic properties also inhibits the growth of cancer cells (Saxena et al., 2012; Xu et al., 2017).

Gastrointestinal disorders are diseases that affect the digestive tract function, such as food and fluid absorption, digestion or excretion. The disorder causes pain, morbidity and can lead to death. Diseases caused by gastrointestinal disorders including 10 major killer diseases in the world. In terms of mortality, causes of death for all age groups diarrheal was $3.5 \%$, ranks 13 th out of 22 causes of death, both communicable and noncommunicable diseases. WHO (2007) conducted a review of the eight countries in the world, shows that the percentage of occurrences due to gastritis in America by $47 \%$, followed by India at $43 \%$ and Indonesia amounted 
to $40.85 \%$, gastrointestinal disorders are abdominal or stomach pain, dysentery, gastroenteritis, constipation and vomiting.

The study of Indonesian plants as medicine gastrointestinal disorders have been conducted, but no studies have inventoried the plant as a drug used to treat gastrointestinal disorders. Therefore, this study aimed to identify the Indonesian indigenous plants with traditional benefits in alleviating types of diseases, used parts of the plants and their phytochemical contents. In addition, potential plants as a source of antioxidants in the treatment of gastrointestinal disorders were determined. Plant inventory and determination of potential levels are expected to institutionalize traditional medicine and alternative pharmaceutical preparations.

\section{Material and methods}

\subsection{Inventory of plants}

Literature reviews published in journals, reports and books dealing with traditional uses of medicinal plants in Indonesia to treat various gastrointestinal disorders were obtained. Different online databases were used PubMed, Science Direct, Scopus, and Google Scholar with specific search terms such as 'medicinal plants', 'Indonesian plants AND gastrointestinal', phytochemical AND phenolic content AND antioxidant activity from each Indonesian plant were have inventoried. The articles obtained are filtered by title, abstract and full text. Articles that are not relevant to the research topic was issued, while the elected subsequently evaluated using inclusion and exclusion criteria for the study. The inclusion criteria used in this review were articles published in the year 2009 - 2019, Indonesian plants, gastrointestinal, ethanol extract, total phenolic content (TPC) expressed in $\mathrm{mg} \mathrm{GAE} / \mathrm{g}$ extract, total flavonoid content (TFC) expressed in $\mathrm{mg} \mathrm{QE} / \mathrm{g}$ extract and antioxidant activity using DPPH (2,2-diphenyl-1 picrylhydrazyl) method expressed in $\mathrm{IC}_{50}$ with ascorbic acid comparison compound (AEAC) from each of these Indonesian indigenous plants. The term 'Indonesian plants' was used to limit the geographical scope of the search. Selection of ethanol extract and DPPH method because many of these are found in this literature search.

\subsection{Phenolic content and antioxidant activity}

Total phenolic content and antioxidant activity were used to determine the potential of Indonesian indigenous plants in treating gastrointestinal disorders. The method used is to compare the phenolic content (TPC) with antioxidant activity. Units of data synchronized with the assumption that the ethanol extract of these plants has the same density $(\mathrm{ml}$ extract $=\mathrm{g}$ of extract). Plants that have the highest potential level value is expressed as the plant with the most potential as a source of antioxidants to treat gastrointestinal disorders.

\subsection{Analysis data}

The analysis data consisted of qualitative and quantitative data. Qualitative data includes the results of an inventory of indigenous Indonesian plants such as species names, local names, families, parts used, and types of gastrointestinal disorders that can be treated using these plants. The results of an inventory of the types of gastrointestinal disorders are categorized based on abnormalities or physiological effects of the plant. This categorizing aims to determine the number of plants that can be used for disorders of the gastrointestinal tract. In addition, qualitative data have also used the presence of bioactive compounds such as phenolic, alkaloids, flavonoids, tannins, saponins, terpenoids and steroids.

Quantitative data is used to express the percentage of the number of plants that can be used to treat gastrointestinal disorders. Determine if the potential level of each plant species were analyzed using the XLSTAT program.

\section{Result and discussion}

\subsection{Potential indigenous Indonesian plants}

The results of the literature search obtained 97 plants that are known to treat gastrointestinal disorders. Then the articles were selected based on title, abstract and availability of the full-text article. Indonesia's inventory of indigenous plants that can treat gastrointestinal disorders is presented in Table 1. Data in Table 1 shows that 51 species are consisting of 32 plant families that are commonly used to treat gastrointestinal disorders. The most dominant family with respect to a number of species used to treat gastrointestinal disorders is Zingiberaceae (ten species) followed by Apiaceae (three species), Solanaceae, Fabaceae, Piperaceae, Annonaceae, Arecaceae, Punicaceae, Acanthaceae, basellaceae and Myrtaceae (2 species) whereas other plants 1 species.

To determine the number of plants that can be used to treat gastrointestinal disorders, the types of gastrointestinal disorders are categorized based on abnormalities similar or physiological effects of these plants such as constipation/laxative/constipation, gastritis/gastric ulcer/stomach pain/carminative/ flatulence and emetic/nausea/vomiting. Types of gastrointestinal disorders are divided into 13 categories (Table 2). Types of gastrointestinal disorders that can be treated with indigenous Indonesian plants are gastritis (24\%), followed by diarrhoea $(15.4 \%)$, digestive disorders $(15.4 \%)$, constipation $(11.5 \%)$, colitis $(8.7 \%)$, 


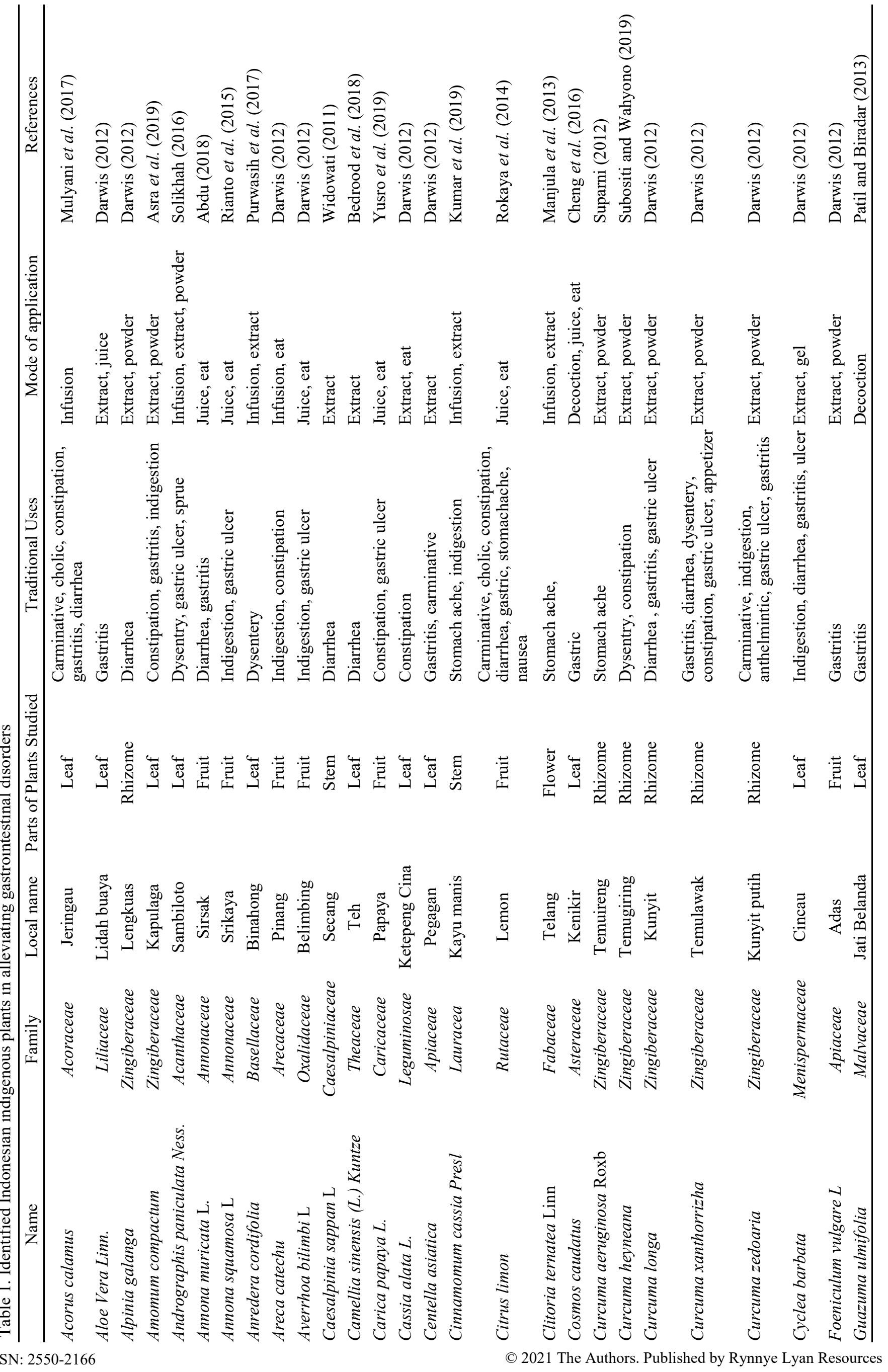




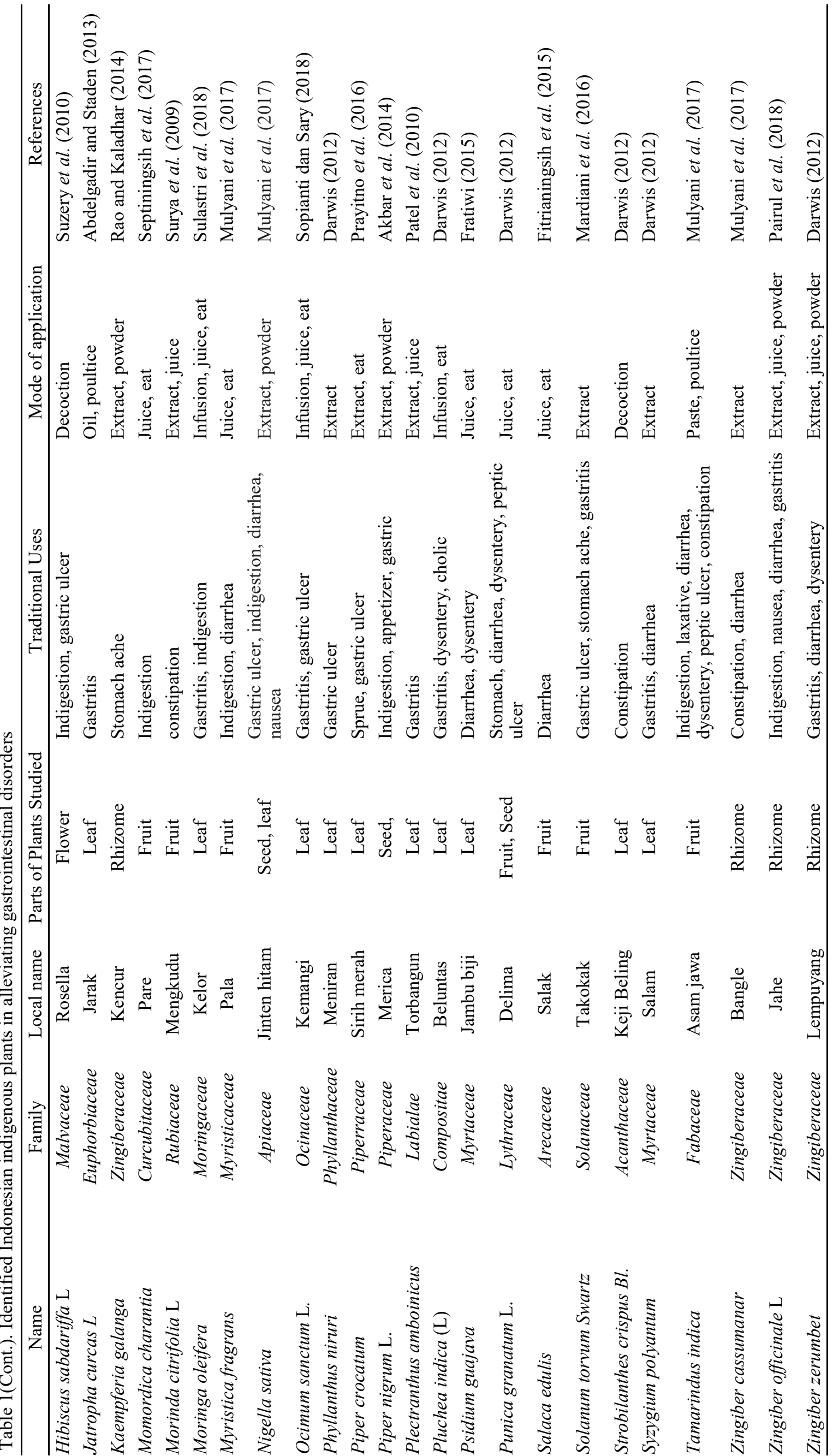


Table 2. Number of plants used to treat gastrointestinal disorders

\begin{tabular}{lccc}
\hline \multicolumn{1}{c}{ Types of gastrointestinal disorders } & Abbreviation & Number of Plants & Percentage (\%) \\
\hline Gastritis / stomach pain / gastric ulcer & Gas & 25 & 24.0 \\
Diarrhea & Dia & 16 & 15.4 \\
Indigestion & Ind & 16 & 15.4 \\
Constipation/laxative & Con lax & 12 & 11.5 \\
Ulcer & Ulc & 9 & 8.7 \\
Stomachache & Sto & 7 & 6.7 \\
Dysentery & Dis & 6 & 5.8 \\
Appetizer & App & 3 & 2.9 \\
Colic & Col & 3 & 2.9 \\
Emetic/vomit & EmeVom & 2 & 1.9 \\
Carminative & Car & 2 & 1.9 \\
Other disease & Oth dis & 2 & 1.9 \\
Anthelmintic & Ant & 1 & 1.0 \\
\hline
\end{tabular}

abdominal pain $(6.7 \%)$ and dysentery $(5.8 \%)$. Some are used to increase appetite, overcome stomach ulcers, nausea, and flatulence.

The results of the literature search also showed that leaves were the most widely used part of the plant with 24 species (44.4\%), followed by 13 species of fruit (24.1\%), 9 species of rhizomes (16.7\%), 3 seeds and flowers each. species (5.6\%) and stems of 2 species $(3.7 \%)$ as can be seen in Figure 1.

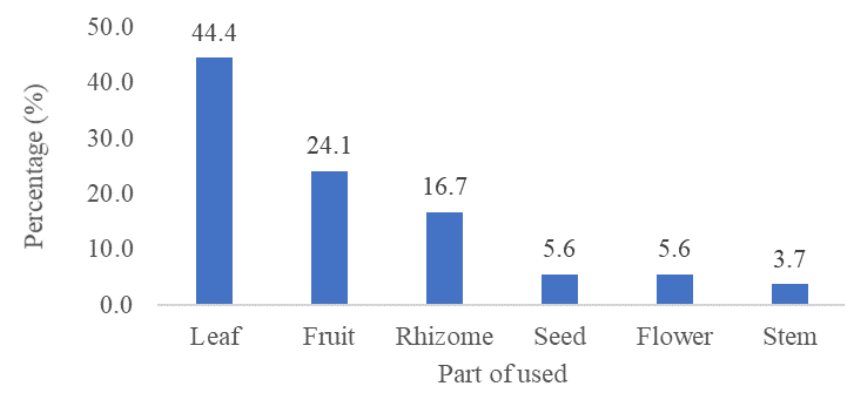

Figure 1. Percentage of plant parts used to treat gastrointestinal disorders

Indigenous Indonesian plants have many bioactive compounds such as phenolic, flavonoids, terpenoids, alkaloids, tannin, terpenoids, saponins and steroids so it can be used to treat several common diseases including gastrointestinal disease. Data bioactive compounds in each plant were extracted using ethanol can be seen in Table 3.

\subsection{Phenolic content, flavonoid content and antioxidant activity of identified indigenous Indonesian plants}

The results of the literature search on phenolic content (TPC), flavonoid content (TFC) and antioxidant activity are presented in Table 4 . Data in Table 4 shows that Zingiber officinale is a plant that has the highest potential level as a source of antioxidant to treat gastrointestinal disorders followed by Annona muricata, Phylanthus niruri, Curcuma longa and Curcuma xanthorrizha.

\section{Conclusion}

This study clearly shows the potential of Indonesian indigenous plants as antioxidant agents to treat gastrointestinal disorders. Pharmacological studies reveal that a diverse group of naturally occurring chemical substances derived from the plants show promising antioxidant activity such as Zingiber officinale, Annona muricata, Curcuma longa and others. Therefore, further research should be carried out on the bioactive compounds present in the particular plants which have the potential as an antioxidant agent, especially to treat gastrointestinal disorders.

\section{References}

Abdu, S.B. (2018). Annona muricata (Graviola): A review of its traditional uses and pharmacological activities. International Journal of Life Sciences Research, 6(1), 50-57.

Abdulkadir, A.R., Mat, N., Hasan M.M. and Jahan, M.S. (2016). In vitro antioxidant activity of the ethanolic extract from fruit, stem, and leaf Solanum torvum. Science Asia, 42(3), 184-189. https:// doi.org/10.2306/scienceasia1513-1874.2016.42.184

Agustina, S., Ruslan and Wiraningtyas, A. (2016). Skrining fitokimia tanaman obat di kabupaten Bima.

Cakra Kimia Indonesian. E-journal of Applied Chemistry, 4(1), 71-76.

Alaga, T.O., Edema, M.O., Atayese, A.O. and Bankole, M.O. (2014). Phytochemical and in vitro antibacterial properties of Hibiscus sabdariffa L. (Roselle) juice. Journal of Medicinal Plant Research, 8(6), 339-344. https://doi.org/10.5897/ JMPR12.1139

Andarwulan, N., Dewi, K., Riza, A.A., Hardianzah, R., Anna, V.R. and Bradley, W.B. (2012). Polyphenols, carotenoids, and ascorbic acid in underutilized medicinal vegetables. Journal of Functional Foods, $4(1), \quad 339-347 . \quad$ https://doi.org/10.1016/ 


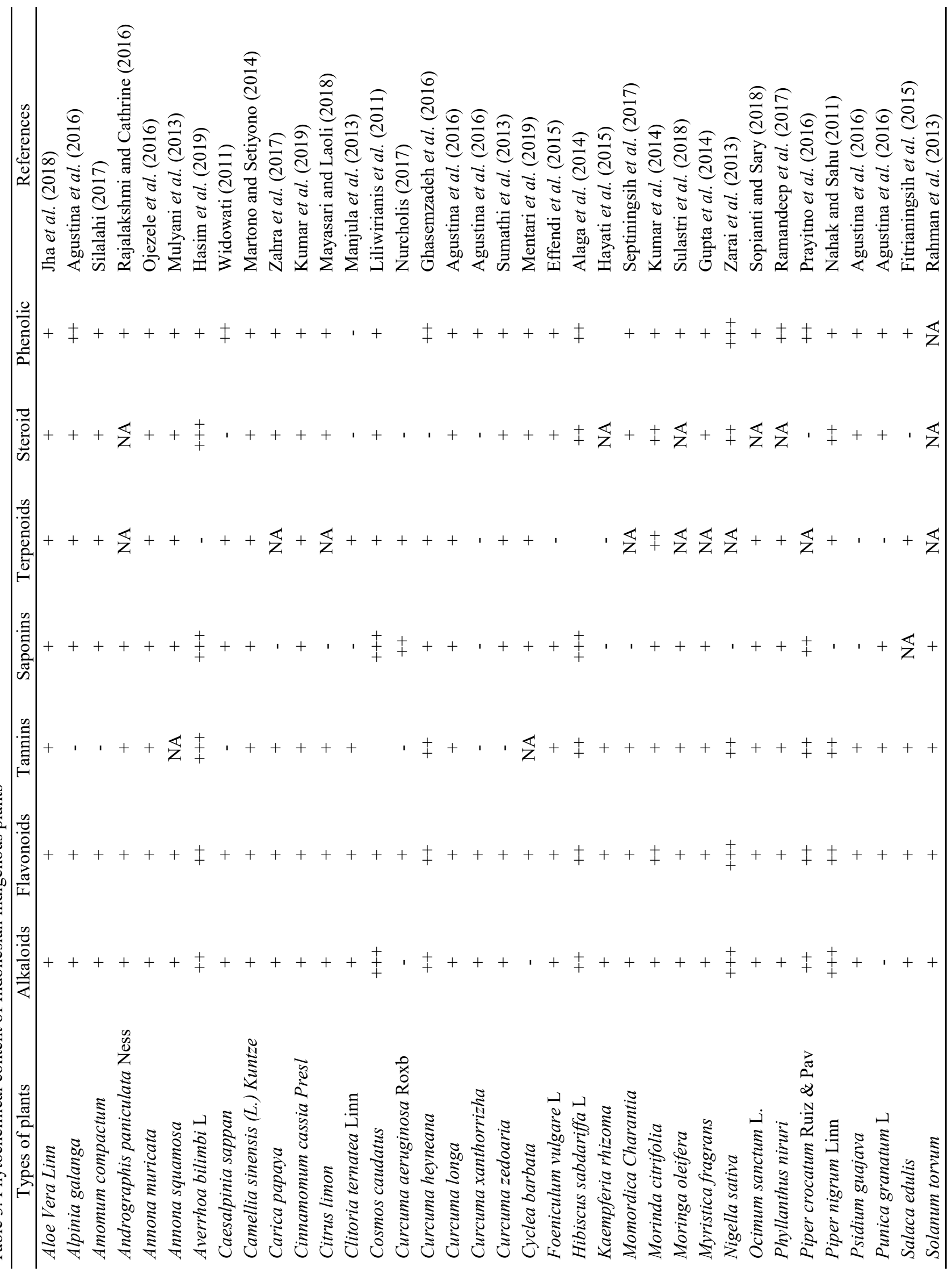




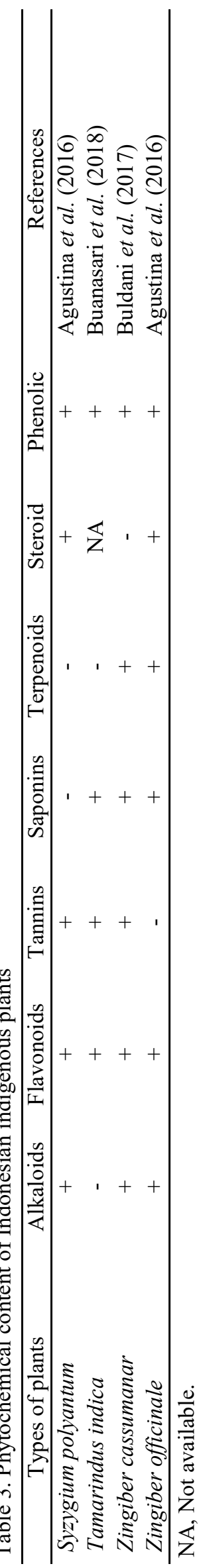

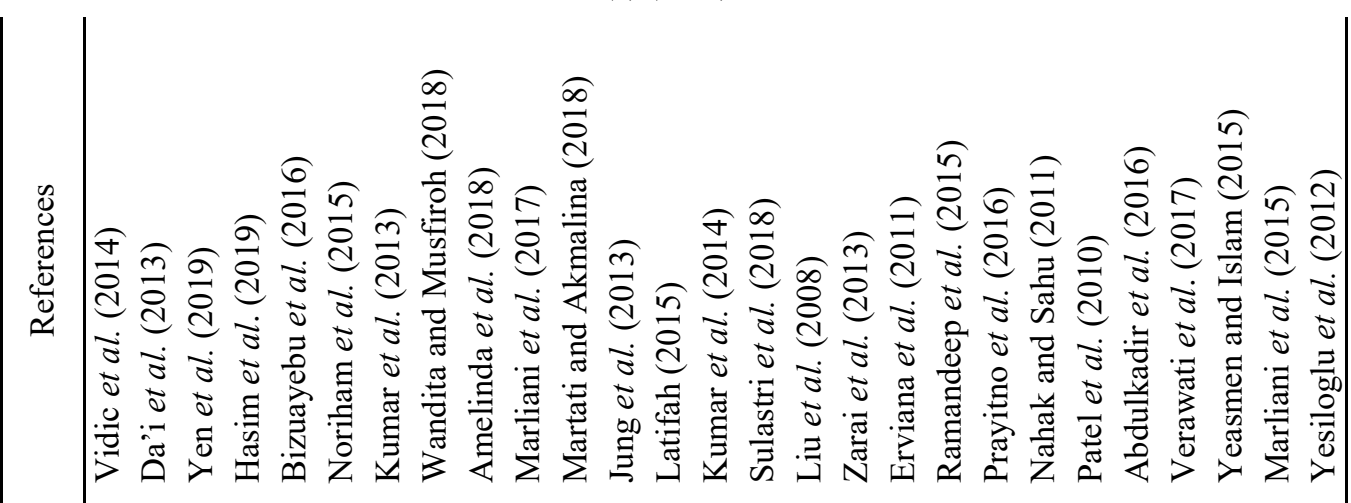

$\overline{0}$

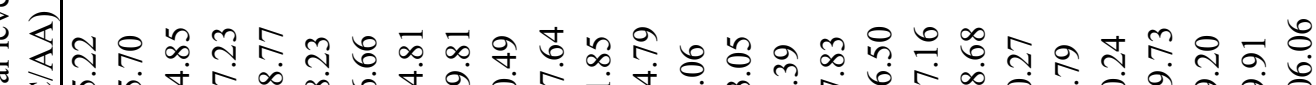

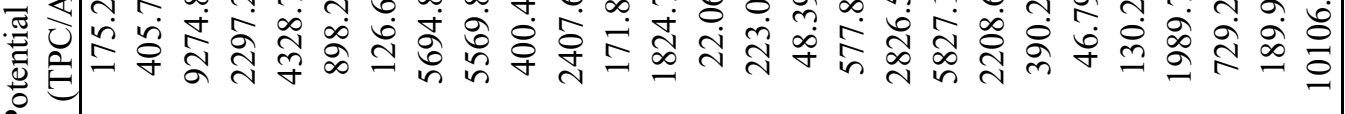
$\stackrel{2}{\circ}$

$\mathbb{4}$

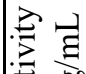

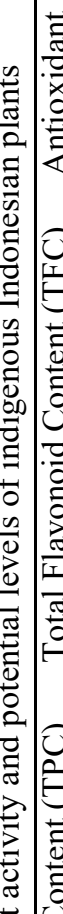

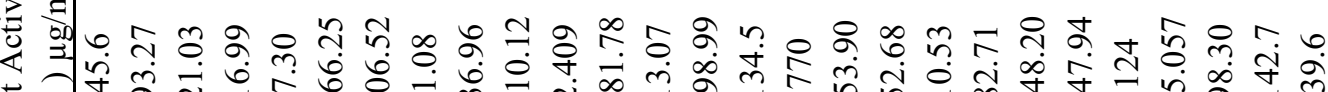
若 บ

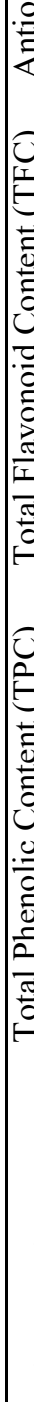

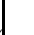




\section{j.jff.2012.01.003}

Amelinda, E., Widarta, W.R. and Damayanti, L.P.T. (2018). Pengaruh waktu maserasi terhadap aktivitas antioksidan ekstrak rimpang temulawak. Jurnal Ilmu dan Teknologi Pangan, 7(4), 165-174. https:// doi.org/10.24843/itepa.2018.v07.i04.p03 [In Bahasa Indonesia].

Asra, R., Azni, N.R., Rudi and Nessa. (2019). Uji aktivitas antioksidan ekstrak etanol fraksi heksan, etil asetat dan air daun kapulaga. Journal of Pharmaceutical and Sciences, 2(1), 30-37. https:// doi.org/10.36490/journal-jps.com.v2i1.17 [In Bahasa Indonesia].

Bedrood, Z., Rameshrad, M. and Hosseinzadeh, H. (2018). Toxicological effect of Camellia sinensis (green tea): A review. Phytotherapy Research, 32(7), 1163 - 1180. https://doi.org/10.1002/ptr.6063

Bizuayebu, D., Atlabachew, M. and Ali, M. (2016). Determination of some selected secondary metabolites and their in-vitro antioxidant activity in commercially available Ethiopian tea (Camellia sinensis). Springer Plus, 5, 412. https:// doi.org/10.1186/s40064-016-2056-1

Cheng, S.H., Barakatun-Nisak, M.Y., Anthony, J. and Ismail, A. (2016). Potential medicinal benefits of Cosmos caudatus (Ulam Raja): A scoping review. Journal of Research in Medicinal Sciences, 20(10), 1000-1006. 1995.172796

https://doi.org/10.4103/1735-

Da'i, M., Wahyuni, A.S., Trisharyanti, I., Azizah, T., Suhendi, A. and Saifudin, A. (2015). Antioxidant activity of Phyllanthus niruri L. Herb: in vitro and in vivo models and isolation of active compound. National Journal of Physiology, Pharmacy and Pharmacology, 6(3), 32-37. https://doi.org/10.5455/ njppp.2015.5.0510201575

Darwis, W. (2012). Tanaman obat yang terdapat di kota bengkulu yang berpotensi sebagai obat penyakit dan gangguan pada sistem pencernaan manusia. Konservasi Hayati, 8(1), 1-15. [In Bahasa Indonesia].|Fratiwi, Y. (2015). The Potential of guava leaf (Psidium guajava L.) for diarrhea. Journal of Majority, 4(1), 113-118.

Ghasemzadeh, A., Jaafar, H.Z.E. and Rahmat, A. (2016). Variation of the phytochemical constituents and antioxidant activities of Zingiber officinale var rubrum theilade associated with different drying methods and polyphenol oxidase activity. Molecules, 2(1), 780-788. https://doi.org/10.3390/ molecules21060780

Gupta, A.D., Vipin, K.B., Vikash, B. and Nishi, M. (2013). Chemistry, antioxidant and antimicrobial potential of nutmeg (Myristica fragrans Houtt). Journal of Genetic Engineering and Biotechnology, 11(1), 25-31. https://doi.org/10.1016/ j.jgeb.2012.12.001

Jha, Prakash, D. and Bisht, D. (2018). A phytochemical screening of the ethanolic extract of Aloe vera gel. International Journal of Science and Research, 8 (10), 1543-1545.

Kumar, S, and Pandey, A. (2013). Chemistry and Biological Activities of Flavonoids: An Overview. The Scientific World Journal, 1-16. https:// doi.org/10.1155/2013/162750

Kumar, K., Suresh, M., Kumar, S.A. and Kalaiselvi, P. (2014). Bioactive compounds, radical scavenging, antioxidant properties and FTIR spectroscopy study of Moringa citrifolia fruit extracts. International Journal of Current Microbiology and Applied Science, 3(2), 28-42.

Kumar, S., Kumar, R. and Mishra, S. (2019). Pharmacological properties and their medicinal uses of Cinnamomum: A review. Journal of Pharmacy and Pharmacology, 71(12), 1735 - 1761. https:// doi.org/10.1111/jphp.13173

Liliwirianis, N., Musa, N.L.N.W., Zain, W.Z.W.M., Kassim, J. and Karim, S.A. (2011). Preliminary studies on phytochemical screening of ulam and fruit from Malaysia. E-Journal of Chemistry, 8(1), 285288. https://doi.org/10.1155/2011/464595

Madikizela, B., Ndhlala, A.R., Finnie, J.F. and van Staden, J. (2012). Ethnopharmacological study of plants from Pondoland used against diarrhea. Journal of Ethnopharmacology, 141(1),61-71. https://doi.org/10.1016/j.jep.2012.01.053

Manjula, P., Mogan, C.H., Sreekanth, D., Keerthi, B. and Prathibha, D. (2013). Phytochemical analysis of Clitoria ternatea Linn, a valuable medicinal plant. Journal of Indian Botanical Society, $92(3$ and 4), $173-178$.

Martono, B. and Setiyono, R.T. (2014). Phytochemical screening of six tea genotypes. Journal of Industrial and Beverage Crops, 1(2), 63-68. https:// doi.org/10.21082/jtidp.v1n2.2014.p63-68

Mayasari, U. and Laoli, M. T. (2018). Karakterisasi simplisia dan skrining fitokimia daun jeruk lemon (Citrus limon (1.) Burm.f.). Klorofil, 2(1), 7-13. [In Bahasa Indonesia].

Mulyani, M., Arifin, B. and Nurdin, H. (2013). Uji antioksidan dan isolasi senyawa metabolit sekunder dari daun srikaya (Annona squamosa 1). Jurnal Kimia Unand, 2(1), 6-12. [In Bahasa Indonesia].

Mulyani, H., Harti, W.S. and Indria, E.V. (2017). Pengobatan tradisional jawa dalam manuskrip serat 
primbon jampi Jawi. Jurnal Literia, 16(1), 135-151. https://doi.org/10.21831/ltr.v16i1.14257 [In Bahasa Indonesia].

Nahak, G. and Sahu, R.K. (2011). Phytochemical evaluation and antioxidant activity of Piper cubeba and Piper nigrum. Journal of Applied Pharmaceutical Science, 1(8), 153-157.

Nurcholis, W. and Bintang, M. (2017). Perbandingan aktivitas antioksidan dan kandungan fenolik temulawak dan temu ireng. Jurnal Jamu Indonesia, 2 (1), 25-29. https://doi.org/10.29244/jji.v2i1.27 [In Bahasa Indonesia].

Ojezele, O.J., Ojezele, M.O. and Adeosun, A.M. (2016). Comparative phytochemistry and antioxidant activities of water and ethanol extract of Annona muricata Linn leaf, seed and fruit. Advances in Biological Research, 10(4), 230-235.

Patel, R.D., Naveen, K.M., Manjul, P.S., Anita, S., Naheed, W.S., Gulzar, A. and Sudarshan, K.S. (2010). Antioxidant potential of leaves of plectranthus amboinicus (lour) spreng. Der Pharmacia Lettre, 2(4), 240-245. https:// doi.org/10.1016/S0975-3575(10)80057-4

Patil, A.B. and Jadhav, A.S. (2013). Flavonoid and antioxidants: A review. International Journal of Pharmaceutical and Biological Sciences Research and Development, 1(2), 7-20.

Prayitno, S.A., Kusnadi, J. and Murtini, E.S. (2016). Antioxidant activity of red betel leaves extract (piper crocatum ruiz and pav.) By difference concentration of solvents. Research Journal of Pharmaceutical, Biological and Chemical Sciences, 7(5), 1836 1843.

Rajalakshmi, V. and Catherine, L. (2016). Phytochemical screening and antimicrobial activity of ethanolic extract of Andrographis paniculate. Journal of Pharmacognosy and Phytochemistry, 5 (2), 175-177.

Ramandeep, K., Nahid, A., Neelabh, C. and Navneet, K. (2017). Phytochemical screening of Phyllanthus niruri collected from Kerala region and its antioxidant and antimicrobial potential. Journal of Pharmaceutical Science and Research, 9(5),13121316.

Rianto, L., Astuti, I., Handayani. and Septiani, A. (2015). Uji aktivitas ekstrak etanol $96 \%$ biji srikaya (Annona squamosa 1) sebagai antidiare dengan metode difusi cakram. Jurnal Ilmiah Manuntung, 1(2), 181-186. https://doi.org/10.51352/jim.v1i2.33 [In Bahasa Indonesia].

Rokaya, B.M., Yadav, U., Poudel, R.C., Timsina, B., Münzbergováa, Z., Asselin, H., Tiwari, A., Shrestha,
S. and Sigdel, S.R. (2014). Traditional uses of medicinal plants in gastrointestinal disorders in Nepal. Review. Journal of Ethnopharmacology, 158 (Part A), 221-229. https://doi.org/10.1016/ j.jep.2014.10.014

Saxena, N., Shrivastara, P.N. and Saxena, C. (2012). Preliminary physicochemical study of stem bark of Alstonia scholaris (L) medicinal plant. International Journal of Pharmaceutical Sciences and Research, 3 (4), 1071-1075.

Silalahi, M. (2017). Bioaktivitas Amomum compactum Soland ex Maton dan perspektif konservasinya. Journal Pro-Life, 4(2), 320-328. [In Bahasa Indonesia].

Solikhah, E.N. (2016). Indonesian medicinal plants as sources of secondary metabolites for pharmaceutical industry. Journal of Medicinal Science, 48(4), 226239.

JMedSci004804201606

Sopianti. and Sary. (2018). Skrining fitokimia dan profil KLT metabolit sekunder dari daun ruku-ruku (Ocimum tenulflorum 1.) dan daun kemangi (Ocimum sanctum l). Jurnal Farmasi dan Kesehatan, 8(1), 4452. https://doi.org/10.36434/scientia.v8i1.118 [In Bahasa Indonesia].

Sulastri., Zubair, M.S., Anas, N.I., Abidin, S., Hardani, R., Yulianti, R. and Aliyah. (2018). Total phenolic, total flavonoid, quercetin content and antioxidant activity of standardized extract of Moringa oleifera leaf from regions with different elevation. Pharmacognosy Journal, 10(6), 104-108. https:// doi.org/10.5530/pj.2018.6s.20

Sumathi, S., Iswariya, G.K., Sivaprabha, B., Dharani, P., Radha. and Padma, P.R. (2013). Comparative study of radical scavenging activity and phytochemical analysis of fresh and dry rhizomes of Curcuma zedoria. International Journal of Pharmaceutical Sciences and Research, 4(3), 1069-1073.

Suzery, M., Lestari, S. and Cahyono B. (2010). Penentuan total antosianin dari kelopak bunga rosella (Hibiscus sabdariffa L.) dengan metode maserasi dan sokhletasi. Jurnal Sains dan Matematika, 18(1), 1-6. [In Bahasa Indonesia].

Vidic, D., Tarić, E., Alagić, J. and Maksimović, M. (2014). Determination of total phenolic content and antioxidant activity of ethanol extracts from Aloe spp. Bulletin of the Chemists and Technologists of Bosnia and Herzegovina, 42, 5-10.

WHO (World Health Organization). (2007). Traditional Medicine Fact Sheet 134. Geneva: World Health Organization.

Widowati, W. (2011). Uji fitokimia dan potensi 
antioksidan ekstrak etanol kayu secang (Caesalpinia sappan L.). Jurnal Kedokteran Maranatha, 11(1), 23 -31. [In Bahasa Indonesia].

Xu, D.P., Li, Y., Meng, X., Zhou, T., Zheng, J., Zhang, J. and Li, H-B.. (2017). Natural antioxidant in foods and medicinal plants: Extraction, assessment and resources. International Journal of Molecular Science, 18(1), 96. https://doi.org/10.3390/ ijms18010096

Yeasmen, N. and Islam, N. (2015). Ethanol as a solvent and hot extraction technique preserved the antioxidant properties of tamarind (Tamarindus indica) seed. Journal of Advanced Veterinary and Animal Research, 2(3), 332-337. https:// doi.org/10.5455/javar.2015.b103

Yesiloglu, Y., Aydin, H. and Ismail, K. (2012). In vitro antioxidant activity of various extracts of ginger (Zingiber officinale 1.) seed. Asian Journal of Chemistry, 25(7), 3573-3578. https:// doi.org/10.14233/ajchem.2013.13657

Yusro, F., Mariani, Y. and Wardenaar, E. (2019). Utilization of medicinal plants to treat digestive system disorders by Dayak Iban Tribe: case study in Kapuas Hulu Regency, West Kalimantan. Jurnal Borneo Akcaya, 5(1), 58-72. https:// doi.org/10.51266/borneoakcaya.v5i1.120

Zarai, Z., Boujelbene, E., Salem, N.B., Gargouri, Y. and Sayari, A. (2013). Antioxidant and antimicrobial activities of various solvent extract, piperine and piperic acid from Piper nigrum. Food Science and Technology, 50(2), 634-641. https://doi.org/10.1016/ j.lwt.2012.07.036

Zahra, Shaheed, S. and Malik, A. (2017). In vitro phytochemical screening and antioxidant activity of Carica papaya plant parts collected from Lahore, Pakistan. Journal of Natural Product and Plant Resource, 7(4), 23-28. 